Der wichtigste hebräische Feiertag, der Sabbat, war ursprünglich eine Feier der vier Mondphasen, und die hebräischen Feste und Festsabbate sind noch heute mit den Mondphasen verbunden. Als Mondgott wird Jahwe als "Stier" dargestellt (Exod. 32, 4; 1. Kön. 12, 28), hat "Adlerflügel" (Exod. 19,4) oder wird wie der babylonische Mondgott als alter Mann gedacht (Dan. 7, 13). Als Mondgott wird er ferner als Gewittergott geschildert (der Mondgott wird bei allen Semiten zugleich als Gewittergott gedacht) und wird häufig direkt mit dem Monde identifiziert. Viele Ausdrücke in der religiösen Terminologie, wie z. B. der Name Jahwe Sebaôt, das "Antlitz" Gottes, Hallelu-ja usw., k̈önnen nur so erklärt werden, dass Jahwe oder Elohim ehemals ein Mondgott war 1.

\section{The Prophecy of Balaam}

\section{(Numbers XXIV 22-24).}

$$
\text { By A. H. Sayce. }
$$

None of the attempts yet made to emend \& explain the text of Numb. XXIV 22-24 has been very successful, \& they have all proceeded upon the assumption that the reading אשור in vv. $22 \& 24$ is correct. But our present knowledge of early oriental history makes it evident that אשור must be corrected into. In the Aramaic alphabet the obliteration of the upright tail of leaves $w$, so that the change of into $\boldsymbol{U}$ is at once frequent \& natural.

The reading בער, Bsì , in v. 22 is certified by the Septuagint, \& therefore instead of correcting it into עבר it would be preferable to change עבר into v. 24. Beor the father of the first king of Edom would represent the Edomites. The political situation is that to which Professor Hommel refers the passage; the Amorites under Sihon had extended their power southward into Moab \& Edom after the decay of the Egyptian empire in Asia, but were themselves attacked by the northern hordes who poured southwards partly by land \& partly in ships, \& after forming their camp "in the land of the Amorites" made their way to the frontiers of Egypt.

The passage will thus read:

"Yet the Kenite shall belong to Beor until Amur shall (enslave thee) ........\& ships from the coast of Kittim, \& they shall afflict Amur \& shall afflict Beor."

1 Fr. Hommel: Der Gestirndienst der alten Araber, München 1901, S. $14 \mathrm{ff}$. D. Nielsen: Die altarabische Mondreligion, Strassburg 1904, S. 49-88, 143-164, 199-203.

\section{רฺ \\ Von Rudolf Růžička.}

Als ein Argument für die vermeintliche Existenz des $\dot{g}$ im Hebräischen wird angeführt, dass es bei mehreren $y$-Stämmen Worte mit so disparater Bedeutung gebe, dass man nótwendig annehmen müsse, diese Stämme hätten sich auch in der Aussprache voneinander unterschieden, und spricht an der Hand des arabischen Sprachmaterials dem einen der Stämme die Aussprache des $y=$ arab. $\varepsilon$ und dem anderen die Aussprache $\operatorname{des} \nu=$ arab. $\dot{z} z u$. Nun kann man nicht leugnen, dass die semitische Etymologie erst in allerersten Anfängen ist, dass von einem systematischen $\mathrm{Be}-$ treiben derselben gar keine Rede sein kann; bei den bisherigen etymologischen Studien wird der wichtige Umstand ausser acht gelassen, dass das semitische Sprachmaterial in Gruppen zerfällt, von denen jede Stämme umfasst, die aus derselben zweiradikaligen Wurzel mit einer bestimmten Grundbedeutung hervorgegangen sind und dass man folglich die Bedeutungsentwickelung eines jeden Stammes immer im Zusammenhange mit den übrigen Mitgliedern derselben Gruppe beurteilen muss, will man der Eigenart des semitischen Sprachmaterials gerecht werden. Durch diese komplizierte Bedeutungsentwickelung der semitischen Stämme erklärt es sich, dass einzelne Stämme so disparate Bedeutungen umfassen, dass es anders als unter Berücksichtigung des eben ausgesprochenen Grundsatzes überhaupt unmöglich ist, diese Entwickelung festzustellen. Dies ist hauptsächlich in dem verhältnismässig am vollständigsten erhaltenen arabischen Sprachmaterial der Fall. Fast jeder Stamm vereinigt bei vollkommen einheitlicher Aussprache so verschiedenartige Bedeutungen, dass sie auf den ersten Blick den Eindruck eines willkürlich zusammengeworfenen Konglomerates machen. Erst der Vergleich der wurzelverwandten Stämme ist in den meisten Fällen imstande, Lichtin dieses Labyrinth ron Bedeutungen za bringen. Daraus ersieht man, wie misslieh es ist, aus verschiedener Bedeutung eines Stammes auf verschiedene Aussprache desselben zu schliessen, und welche schwache Stïtze auch dieser Umstand für die These vom ursemitischen $\dot{g}$ bietet.

Ich will nun hier vorläufig an einem Beispiele zeigen, wie leicht man sich in dieser Beziehung täuschen kann. So wird רפุำ Staub und Junges, Kalb von Hirsch, Reh oder Gazelle (Ct. 2, 9, 17; 4, 5; 7, 4; 8, 14) auseinandergehalten und für das erstere die Aussprache mit 'nach dem arabischen 